\title{
A World Security Community of Democratic Nations
}

\author{
Christopher John Hamer \\ ${ }^{1}$ President, Coalition for a World Security Community. \\ ${ }^{2}$ School of Physics, University of New South Wales, Sydney, Australia.
}

How to cite this paper: Christopher John Hamer. (2021) A World Security Community of Democratic Nations. Journal of Humanities, Arts and Social Science, 5(2), 192-203.

DOI: $10.26855 /$ jhass.2021.07.003

Received: June 18, 2021

Accepted: July 15, 2021

Published: August 4, 2021

*Corresponding author: Christopher John Hamer, President, Coalition for a World Security Community; School of Physics, University of New South Wales, Sydney, Australia

Email: C.Hamer@unsw.edu.au

\begin{abstract}
Humanity faces some catastrophic risks to our future well-being. Foremost among them are the new dangers posed by unchecked global warming, and the ongoing threat of nuclear annihilation. It is clear that all of us as world citizens must work together to counter and remove these risks, and for this purpose we need stronger institutions of global governance. Ideally we need a world government, some form of democratic world federation, where our representatives can decide what needs to be done collectively to solve these problems, and have the power to implement these decisions by means of binding laws and regulations. Democracy must be a fundamental principle of any such system, in order to uphold basic human rights and to guard against any danger of tyranny or autocracy at the global level. Up till now, however, all attempts to reform the United Nations in this direction have failed. We propose as a first step towards a safer world that democratic nations around the globe should join together to form a World Security Community, embracing various existing alliances such as NATO and the Quad. Acting strictly in conjunction with the UN Security Council, this Community would form a very powerful new force for peace and security in the world. It would be able to guarantee the security of all its members, and also provide powerful new facilities for peace building in the wider world in collaboration with the UN. We explore a possible structure for such a community, and its advantages, in some detail. Such a community would form a natural starting point for the evolution over time of a genuine global parliament, copying the strategy of stage-by-stage international integration which has led to the present European Union. Working alongside the OECD, which should also deepen collaboration among democracies on collective economic, social and environmental policies, the new Community would lay the foundations for our ultimate vision of a democratic world federation able to deal effectively with all our global problems and catastrophic risks. The upcoming Summit for Democracy proposed by President Biden should offer a golden opportunity for progress in this direction.
\end{abstract}

Keywords

Democracy, World Federation, Community of Democracies

\section{Introduction}

All human beings, regardless of their nationality, have many fundamental interests in common, and face some enormous common problems and catastrophic risks. An authoritative recent report from the Commission for the Human Future (2020) in Australia, for instance, enumerates ten 'global catastrophic risks' which we need to address. 
They include

- Global warming and other forms of damage to the environment have become an alarming new threat to our children's heritage. This could be humanity's greatest challenge.

- Seventy years after World War II, mankind still faces a looming threat from nuclear weapons. There are still many thousands of nuclear warheads in existence, which have the potential to literally destroy human civilisation as we know it.

- Conflicts and wars have displaced around 70 million people, a number greater than the entire population of France, forced to abandon their homes or become refugees.

- Billions of the world's poor still face the ever-present dangers of famine, disease and war. Each day, to our shame, many thousands of children still die needlessly.

- The basic human rights of many thousands of people are trampled on every day, without means of redress.

It is obvious that global problems need global solutions, and clearly, the nations of the world must work more closely together to find solutions to these challenges.

Ideally, we need some form of world government to deal with these problems. The function of government, after all, is to serve the common needs and deal with the common problems of a society. This was dramatically expressed by Albert Einstein long ago in his famous statement (Nathan \& Nordern, 1968):

"In my opinion, the only salvation for civilisation and the human race lies in the creation of a world government, with security of nations founded upon law".

This still remains the only final solution to the problem of nuclear weapons.

But what form should this world government take? Since it will involve uniting almost two hundred independent nation states, it will be some form of federation. And to guard against any possibility of world tyranny or autocracy, it must be democratic. So we need some form of democratic world federation, including a global parliament, which would be empowered to make binding laws and regulations in order to deal effectively with all these global issues. The present United Nations is not adequate to the task.

A very difficult question is, how do we get there from here? The world federalist movement has been grappling with this problem ever since World War II (Baratta, 1989; Leinen \& Bummel, 2018). The movement has mostly concentrated on the most obvious route, campaigning for reform of the United Nations, which is the peak institution of global governance which we have at present. They have always run up against the obstacle of the rigid UN Charter, which requires the consent of two-thirds of the member states, including all five permanent members of the Security Council (the P5), for any amendment to come into force. The Charter itself provides (Article 109) for a Review Conference to be held in 1955, ten years after the founding of the UN The onset of the Cold War put paid to that idea; and in fact no Charter Review Conference has ever taken place in the years since. It is extremely difficult to get widespread agreement on exactly what reforms are necessary; and for instance, any proposal to remove the veto powers of the P5 members of the Security Council would be vetoed by the P5 members themselves.

The basic problem is that the UN is at its core an Alliance of the victorious Great Powers after World War II (the P5) to keep the peace, following an old model dating back to the Congress of Vienna after Waterloo. Furthermore, the UN involves a large number of non-democratic states, which makes it an unsuitable starting point for a democratic world federation.

As an aside, let us note that in these circumstances the world federalist movement (WFM-IGP) has concentrated its attention on reforms that do not require any amendment of the UN Charter. Under its former Executive Director Bill Pace, it had notable successes in its campaigns for the establishment of the International Criminal Court, and the doctrine of the Responsibility to Protect. One of the most lively current initiatives on this front is the Campaign for a United Nations Parliamentary Assembly (CUNPA, Leinen \& Bummel, 2018), aiming to introduce at least some elements of democratic representation into the UN system.

Uniting seven billion people in nearly two hundred countries - each jealous of its sovereignty-is an enormous task. Like climbing Mount Everest, it will not be achieved in a single giant bound. We will only get there gradually, through a series of base camps (Yuncker, 2018). In the Schuman Declaration (1950) the founding document of the European Union, it is stated that “Europe will not be built in a day, or according to a single plan”. The same applies to the global system of governance.

Jean Monnet and his collaborators at the founding of the European Coal and Steel Community (Mackay, 1969; Monnet, 1978) have provided the example or template for international integration, by starting from a smaller group of member nations (the original 'Six'), and proceeding stage-by-stage through a series of Treaties to build up the European Union and the European Parliament that we see today. The EU is going through some trials and tribulations 
at the moment (e.g. Brexit), but the primary objective is secure-there will almost certainly never again be a war between France and Germany. Now we need to emulate that process at the global level.

On the global stage, the integration process should start with the democracies (Streit, 1939; Hamer, 1998). To guard against autocracy and abuse of power, and to preserve the liberty, human rights and equality of all its citizens, any world federal government must be chosen by means of free and fair elections, with guaranteed freedom of organized groups to stand in opposition to the government in power. Democracy is the only form of government with a 'safety valve', whereby the people can replace the government if it is doing a bad job. And a more practical reason for restricting membership to democratic states is that democracies are demonstrably more peaceful, and less prone to internal conflict, as documented by the Institute for Economics and Peace (IEP, 2020).

Following the European example, we argue that the path toward a democratic world federation should start with a World Security Community of democratic nations, which could itself evolve out of today's North Atlantic Treaty Organization (NATO). Democratic nations could lead the way, with a security community open to all countries meeting appropriate criteria. That community could then progressively expand over decades of time to take in the entire world. Through collaboration with other bodies, particularly the Organization for Economic Cooperation and Development, it could also progressively expand its mandate to tackle other global challenges like economic development, climate change, financial stability, and trade.

Ideas of this sort are not new. Even before World War II, the journalist Clarence Streit argued for a Union of Democracies to combat the fascist powers (Streit, 1939). His ideas spawned a whole civil society movement, the Atlantic movement, aiming to promote integration between the democracies in Europe and North America (Deutsch, 1957). The idea of a League or Concert of Democracies was floated anew about fifteen years ago by a number of politicians and academics (Ikenberry \& Slaughter, 2006; McCain, 2007; Daalder \& Lindsay, 2007).

The recent election of Joe Biden as President of the US offers an exciting opportunity to push forward these ideas. President Biden wrote an article in the March/April issue of Foreign Affairs last year entitled 'Rescuing U.S. Foreign Policy after Trump' (Biden, 2020). The centrepiece from our point of view was the promise that during his first year in office, 'the US will organize and host a global Summit for Democracy to renew the spirit and shared purpose of the nations of the free world. It will bring together the world's democracies to strengthen our democratic institutions, honestly confront nations that are backsliding, and forge a common agenda'. He specifies three areas for discussion: fighting corruption, defending against authoritarianism, and advancing human rights.

In the next section, a possible structure for the new Community is presented in some detail. The following section gives some background, and puts this proposal in the context of previous work. Then we discuss the benefits and advantages of the design in bringing about peace and security. Next, we review the present opportunity for progress in this direction, and its political feasibility. Finally, our conclusions are summarized.

\section{A possible structure of a World Security Community}

Here we review the structure proposed by the Coalition for a World Security Community of democratic nations (Coalition, 2018). It rests on the following basic principles:

(1) The Community would be a defense alliance ("All for one, and one for all”) and its primary mission would be to guarantee the security and freedom of all its members. Its secondary mission would be to act as their peace building and peacekeeping arm in the wider world, under the aegis of the United Nations. It should include or embrace existing defense alliances among democracies, such as NATO, and the new Quad alliance in the Asia-Pacific.

(2) The Community would be a global organization with its membership open to all states committed to democracy, human rights and international law. The membership requirements could be as follows:

a) Democracy and human rights (Jacobs, 2007): The founding members would define a list of human rights required for membership and candidate members would need to figure out for themselves whether they are ready to adopt them or not. In the short term, most of the 87 nations rated as 'fully free' by Freedom House should be eligible without major institutional reforms (Freedom House, 2018). In the long run, it is envisaged that the Community would become universal, as democracy eventually spreads to the rest of the globe.

b) International law: Community members should not commit aggression; they should use force only in collective self-defense, or when authorized (and indeed called for) by the UN Security Council, in compliance with Articles 2.4 and 51 of the UN Charter. Members of the community should pledge to settle any disputes among themselves by peaceful means, according to international law or by mechanisms set up by 
the community itself. Community members should also accept the binding jurisdiction of the International Court of Justice to settle disputes with external states peacefully.

c) Military readiness: Members should contribute their fair share to the collective defense burden by allocating a certain amount to their military budget according to a formula set from time to time by the Community according to the evolving geopolitical environment. Their armed forces should pass an assessment of inter-operationality with other members' armed forces carried out by the Community's Secretariat.

The detailed structure of the Community can only be determined by the commission set up to draft the new Treaty establishing the organization. But possible elements, following the European template, might include:

(3) Avoid the dysfunctional consensus decision-making system that plagues most intergovernmental organizations including NATO by adopting a 'qualified-majority' voting system, preferably at all levels, as advocated in the past by senior military officials (Jones, 2007; Naumann et al., 2007). Such a scheme has been used by the European Union. This would transform the alliance into a 'security community', which we are proposing might be named the World Security Community of democratic nations.

(4) To ensure compliance with its rules, the Community should have the power to suspend the voting rights or even expel members that fail to meet the membership requirements or implement decisions. It might also involve a category of Associate Membership, for those states who do not qualify for full membership, but do pledge to abide by the rules of the Community.

(5) The Community should also channel a fraction of its funds to new peacebuilding facilities, to help prevent future conflicts, and reconstruct failed states after previous conflicts, in collaboration with the new Peacebuilding Commission at the United Nations.

(6) Structure the organization with prototype organs of democratic governance, following the pattern pioneered in Europe:

(a) The Community should have a Supreme Council of heads of state or government meeting periodically to approve broad Community policy. NATO already has the North Atlantic Council to fulfil this role.

(b) The Community should have a Council of Ministers from the member states meeting regularly to prepare and approve detailed policy decisions, as in Europe.

(c) The Community should have a Secretariat of civil servants, whose role would be to oversee the day-to-day operations of the Community, and prepare detailed policy proposals for approval. It could be headed by a Commission on the European model. Within NATO, a bureaucracy in Brussels already exists, headed by the Secretary-General, and the regular budget of NATO is about \$6 billion per annum, which is already larger than the UN core budget.

(d) The Community should establish a Parliamentary Assembly, as the nucleus for an eventual elected parliament. NATO already has the NATO Parliamentary Assembly, which could play this vital role.

(e) A Court should be established to settle differences over the interpretation of the founding treaty, and arbitrate any intractable disputes between the member states. This would form the embryo of an eventual system of binding world law.

In addition, three institutional reforms are proposed for the Organisation for Economic Cooperation and Development (OECD) in order to deepen relationships among democracies in partnership with the Community, and contribute to solutions to global catastrophic risks in fields beyond peace and security.

a) The OECD should revise its membership requirements and accession process, such that its membership largely but not necessarily entirely overlaps with that of WSC.

b) The OECD should start convening summits of its members' heads of state concurrently with the WSC to coordinate their economic, social and environmental policies.

c) The OECD should channel funds to foster development in the less developed, full member states under the principle of 'solidarity' established by the European Union. This would promote a feeling of community among the member states, and provide a strong incentive for new states to join in (Yuncker, 2014).

Such an association would be much more flexible than the UN, able to change and grow through successive treaties, and could indeed form the nucleus for an eventual full-scale system of democratic global governance.

\section{Background to the proposal}

With the collapse of the Soviet Union in 1991, NATO lost its original role as bulwark of Western Europe against a possible Soviet attack. Since then it has been slowly developing a new role, remaining as an umbrella organization for 
the defence of the Atlantic democracies, but now also acting as their "out of area” security and peacekeeping arm, first in Bosnia, then in Afghanistan and Libya. Members of the EU are still debating whether they should continue to rely on NATO for their collective defence, or establish their own European armed forces.

A number of Eastern European countries have recently joined NATO, which now has 30 members. This puts the old consensus model of decision-making under great strain. At his parting session with the Atlantic Council in 2007, General James Jones, the outgoing Supreme Allied Commander-Europe, called for a stronger political structure for NATO (Jones, 2007): "Sooner or later, NATO will have to address whether you want 350 committees all acting on the rule of consensus", he said. "What's the logic of one or two countries being able to block action by the remaining 24 members? Why not have a system where they can just opt out?"

Later, a group of five very distinguished military men put forward (Naumann et al., 2007) a 'Grand Strategy' for renewing NATO, echoing General Jones' call. They were all former chiefs of staff in their respective countries (the US, Britain, France, Germany and Holland), headed by General John Shalikashvili of the US. Among many other suggestions, they suggested a shift in NATO decision-making from consensus to majority voting, and the abolition of national caveats in operational matters. This change alone would transform NATO from a mere alliance into a genuine Community.

Along with new members, many countries further afield have become NATO "Partners". It is therefore not a huge step to envision expanding NATO membership to democracies outside the traditional boundaries of Europe and North America. Former Spanish Prime Minister Aznar advocated just such an expansion (Aznar, 2006). Emphasizing the new threat of terrorism, he argued that NATO should develop a new dimension of homeland security to counter it, including integration of intelligence information and security services across all the democracies. He thus concluded that stable democracies such as Japan and Australia should be invited to join. This call was echoed on the other side of the Atlantic by Senator John McCain during his 2007 run for the US presidency, who advocated a League of Democracies (McCain, 2007). Reinforcing this theme, the former Danish Prime Minister and Secretary-General of NATO, Anders Fogh Rasmussen, has recently published a book offering a bold plan for an Alliance for Democracy, a "strengthened American and European alliance, joined by like-minded liberal democracies such as Japan and Australia, to create a military, political, and economic bulwark against the forces of tyranny" (Rasmussen, 2016).

Many of these changes have also been called for by the NATO Parliamentary Assembly (Resolution, 337). Academics have further debated the concept of a League or Concert of Democracies (Ikenberry \& Slaughter, 2006; Daalder \& Lindsay, 2007).

In recent years, NATO has been recalled towards its original purpose by the revanchist behaviour of Russia under Vladimir Putin. Russia was alarmed and suspicious when its former Soviet satellites in the Baltic states and Eastern Europe elected to join NATO after the breakup of the Soviet Union. Russia's recent annexation of the Crimea, and destabilisation of the eastern Ukraine, has in turn alarmed the Baltic states and the Eastern Europeans, fearing that they may be the next Russian targets. They have called for more concrete support from NATO as insurance against such a possibility, and indeed NATO has responded to these requests. At the Warsaw summit in 2016, NATO members agreed on steps to "reinforce our collective defence, enhance our capabilities and strengthen our resilience" (Warsaw, 2016).

\section{Advantages and Benefits}

Let us look at the advantages of such a scheme from several different points of view.

\subsection{Member States}

For the member states of the Community, such a scheme would provide a virtually ironclad guarantee of their own security against any challenge from autocratic states such as China or Russia. The strength of such a Community, amounting to something close to two-thirds of the total military expenditure and economic output of the entire world, should effectively deter any overt aggression from occurring in the first place.

It would also enable them to share the responsibility, and pool their resources, in providing for the common defence and carrying out peacekeeping and security operations.

\subsection{Non-member states}

For non-member states in general, the promise of guaranteed security and structural development funds from the Community should encourage many new states to brush up their democratic credentials and apply to join, following 
the European example. The creation of powerful new peacebuilding facilities should help to reduce conflict in the outside world, subject to the limitations of the present UN system.

For the great powers China and Russia, the stipulation that the Community should only intervene with military force outside its borders with the authorization of the UN Security Council would mean that they could veto any proposed attack on them by the Community, thus ensuring their own security and hopefully preventing the outbreak of a new Cold War. The Community and the autocracies should be able to agree together on measures to combat other global problems such as climate change.

\subsection{Members of NATO}

For the present members of NATO, the scheme would cure the dysfunctional decision-making procedure presently operative within NATO. It would provide a new legal framework for settling international disputes between members. And it would effectively give NATO an extended and hugely important mission for the future towards achieving world peace.

\subsection{Members of the OECD}

For members of the OECD, things become a little more complicated. There is a large overlap between the countries who are members of NATO and the OECD. Some 22 countries are members of both organizations.

There are 6 countries which are members of NATO but not the OECD, namely Albania, Bulgaria, Croatia, Latvia, Lithuania, and Romania. They would presumably be happy to become members of the new Community.

On the other hand, there are 12 countries which are members of the OECD but not NATO, namely Australia, Austria, Chile, Finland, Ireland, Israel, Japan, Korea, Mexico, New Zealand, Sweden and Switzerland.

Several of these latter countries are neutrals, including Austria, Ireland, Sweden and Switzerland. Japan has a well-known clause in its Constitution forbidding the formation of armed forces. These countries might be happy to join the new global Community, however, given its dedication to ensuring the peace and security of all. For there has been considerable internal debate recently within Sweden and Finland, for example, as to whether they should in fact join NATO, fuelled by the revanchist behaviour of Russia. If NATO were to become a global security community, working in conjunction with the UN, that might very well tip the balance and persuade Sweden and other neutrals to join the new organisation.

Others in this group are not now members because they lie outside the North Atlantic area, but they are already allied with the US under individual defense treaties. Australia and New Zealand, for instance, are already allied with the United States under the ANZUS Treaty, which is seen as the bedrock of their security. They also share intelligence with the United States, Britain and Canada via the 'Five Eyes' network. Australia had the largest contingent of troops of any non-NATO nation in the Afghanistan campaign, for example. Japan also has a strong bilateral defence treaty with the United States. Joining the new Community could only strengthen their collective security, and would help to counter the perceived threat of growing Chinese influence in the Pacific. Already there has been some talk of a "NATO of the Pacific" (Thomas, 2018).

\subsection{The UN}

Acting in tandem with the UN, the new Community could bring important advantages.

- Acting strictly at the behest of the Security Council, the Community would provide a powerful means of enforcement for the resolutions of the Council. It could play a role very like that originally envisaged for a standing security force under Article 47 of the UN Charter, in collaboration with other countries volunteering their resources. It would only intervene in an external state if authorized to do so by the Council; but conversely, like its member states, it would be obliged to lend support to any security enforcement actions which were in fact mandated by the Security Council, under article 43 of the Charter. It would thus provide a strong right arm to back up any security actions of the UN.

- Furthermore, the new Community could quite easily set up reaction units to carry out the role advocated for UNEPS, the proposed UN Emergency Peace Service. It could and should also set up mechanisms to reconstruct failed states after conflict, perhaps a Reconciliation and Reconstruction Commission, following the outstanding example of the Marshall Plan after World War II. This would give the Community a very positive role to play in healing the wounds created by armed conflict, something conspicuously absent after the recent overthrow of regimes in Iraq and Libya. Such developments would be in full accord with the role of the new Peacebuilding Commission at the UN.

Thus, the UN and the Community together would make up a greatly strengthened and more effective system of 
common security and international governance.

\subsection{Emerging democracies}

Most Latin American countries, as well as India, Indonesia, South Africa, and some other democratic countries in Africa and Asia would likely soon qualify to apply for membership in the Community. They would benefit from the guaranteed security offered by the Community, as well as the pooling of resources and access to WSC expertise. Joining the WSC would give them more influence and the opportunity to play a more active role in global affairs. That is also true of joining the OECD.

To attract these countries, the Community will need to shed the perception of 'Western imperialism' that NATO has suffered from in some quarters. Strict respect of the UN authority and genuine democratic power sharing within the Community are necessary in that regard.

Many countries in the 'global South' would not immediately qualify to join the Community. They would still wield the same influence as at present through the United Nations, however. Furthermore, the 'Arab spring' a few years ago testified to the yearning for democracy among young people worldwide, and we would expect more countries in the global South to join up as their governance systems improve. In Africa, Tunisia, Botswana, and Senegal might already qualify as candidates, along with South Africa, for instance.

\subsection{Russia and China}

During the Cold War, the USSR looked on NATO with fear and suspicion, regarding it a threat to their very existence. Russia evidently continues to hold that viewpoint today, while China and the US view each other as rivals. But if the new Community could only intervene with military force outside its borders when authorized by the Security Council to do so, then Russia and China would effectively have a veto over Community operations in the outside world. This should allay their fears, especially when combined with the promise that they could eventually earn entry into the Community themselves.

Submitting the Community to UN authority would reaffirm the grand bargain between the biggest military powers that created the UN. The Community, Russia and China would have to work together as equal partners to promote peace and security outside of their borders. Surely one should expect the UN's performance to improve overnight

Of course we would look forward to the day when Russia and China do qualify to become full members of the Community. At that point, the struggle for world peace would virtually be over. One possibility here is that the Community could create an Associate Member category of aspiring full members who may not qualify as full democracies, and invite Russia to join on that basis, since Russia professes to be a democracy, and does hold elections. Since all members pledge to settle disputes by peaceful means, that would immediately guarantee peace for the border regions between Europe and Russia, at least.

\subsection{Other authoritarian states}

The Community's military power will make wars against its members extremely unlikely. By renouncing violence without UN approval, the Community will forsake wars of aggression outside its borders. The only violent conflicts that will continue are conflicts between, or within, states that are not members of the Community. If the world continues to grow more unstable, democratic states will have a strong incentive to join the Community. Only authoritarian states would remain vulnerable to wars. As the Community together with Russia and China builds trust over time, some conflicts among or within authoritarian states could also be contained or resolved, but probably not all of them. In the end there is no panacea and peace will not be achieved in a day. The Community is meant to act as a pioneer of peaceful resolution of conflicts, but it will not impose itself onto the rest of the world. It must expand by attraction, not coercion.

One of the Republican contenders for the U.S. Presidency in 2008, John McCain, proposed the formation of a 'League of Democracies' in order to build an enduring peace based on freedom (McCain, 2007). "We Americans must be willing to listen to the collective will of our democratic allies”, he said. On the Democratic side, Ivo Daalder, formerly the U.S. Permanent Representative on the Council of NATO, together with James Lindsay, proposed a 'Concert of Democracies' in order to form an “international institution capable of prompt and effective action both to prevent, and where necessary respond to threats to international security” (Daalder \& Lindsay, 2007). The idea of a Concert of Democracies was also promoted in an authoritative, bipartisan report from the Princeton Project, "Forging a World of Liberty under Law" in 2006 (Ikenberry \& Slaughter, 2006). So it seems there could be support for such 
ideas from both sides of politics in the U.S.

\section{Possible Problems}

\subsection{Polarization of the international community}

Non-member states of the new Community may feel excluded, and suspicious of the motives behind it. If the Community interfered in their affairs, they would feel resentful, and would tend to regard the Community as an "enemy", creating a split between "us" and "them". Such a polarization of the international community should be avoided at all costs.

Thus it would be important to make overtures to non-members, as the far-seeing Harmel Report recommended for NATO many years ago (Harmel, 1967). It should be emphasized that membership of the Community is open to all countries, provided only that they satisfy suitable criteria for democratic governance and peaceful relations with their neighbours.

Furthermore, the Community should guarantee never to undertake a military intervention in a non-member country, unless authorized to do so by the Security Council of the UN. This would be a contentious issue in the US in particular. Giving Russia and China a veto over the external interventions of the Community would place severe restrictions on the role the Community could play in serving US interests. But in fact such a policy is obligatory under international law, as laid down in the UN Charter (Articles 2 \& 42). It would also allay fears in Russia and China that the new Community was aimed against them.

\subsection{Conflict with the role of the UN}

A related problem is that the Community might be seen as competing with the role of the UN, in that both would be global security organizations. It will be vitally important to demonstrate that the Community would function in a manner complementary to the UN, rather than competing with it. Again, the Community should only intervene in a non-member state at the behest of the Security Council. The forces at the Community's disposal would then provide powerful reinforcement to the decisions of the Security Council. In fact, they would effectively supply the place of the standing armed forces originally envisaged for the UN under Article 47 of the Charter.

In summary, far from conflicting with the role of the UN, the new Community would fit in very neatly as the Security Council’s strong right arm.

\subsection{Forcing 'Western' values on other cultures}

It might be charged that requiring democracy of new members is tantamount to forcing Western ideas of government onto what is meant to be a global community. But that is not a sustainable argument. Government "of the people, by the people, for the people" is a universal concept, not a purely Western one, and the thriving democracies in Japan and India are convincing examples of this. As more non-Western members join the Community, these fears should quickly be allayed.

\section{The Present Opportunity}

In recent years, both the power and influence of China have increased dramatically. Its economy has advanced by leaps and bounds, so that it is now second only to the USA in size, and is predicted to overtake the US by about the year 2028. Its military resources have increased proportionally.

Under President Xi Jing-Ping, China has begun to take a more assertive attitude in international affairs. It has begun its 'Belt and Road' initiative, wherein it has been accused of 'debt trap' diplomacy, in order to influence other states around the world, and build its new 'Silk Road' to Europe. It has fortified islets within its 'nine-dashed line' in the South China Sea, in defiance of competing claims from other states such as the Philippines, Vietnam, and Japan, and in spite of a judgement of the Permanent Court of Arbitration at The Hague against it. It has moved to crush democracy in Hong Kong. And it has threatened to take back the democratic, self-governing territory of Taiwan within six years, by military force if necessary.

This has coincided with a slow decline in democracy around the world, and a corresponding increase in autocracy, over the past fifteen years or so, as documented by Freedom House (2021), or the Institute of Economics and Peace (IEP, 2020).

All this has alarmed the US and its allies, and raised many calls to stem the tide, by means of greater cooperation, and indeed integration, among the democracies. 
President Biden has promised to convene a Summit for Democracy 'to renew the spirit and shared purpose of the nations of the free world' (Biden, 2020). The hope is that this Summit will not be merely a one-off event, but set an agenda for democratic renewal in the future.

UK Prime Minister Boris Johnson has during his chairmanship of the Group of Seven (G7) included democratic allies such as Australia, India, South Africa and South Korea as observers. This could lead to the formation of a Democracies 10/11, which would strengthen cooperation among the world's major democracies.

The Alliance of Democracies Foundation was founded to unite the world's democratic forces to counter rising authoritarianism. At the 2021 Copenhagen Democracy Summit, the Foundation launched the Copenhagen Charter (2021) which proposes three specific areas for returning democratic multilateralism to its ascendancy.

And the Coalition for a World Security Community of Democracies has proposed the formation of not merely an alliance, but a global community on the European model, open to all countries committed to democracy, human rights and international law (Coalition, 2018).

The most likely institutional outcome of the Summit for Democracy is that a decision will be made to create a D10/11, a regular leader's meeting of the leading democracies around the globe. But the leaders may feel the need to create a more powerful institutional structure to implement their decisions. The outcome largely depends on how bold a proposal President Biden is willing to put to the Summit.

Points in favour of creating a Community such as we have proposed include the following, from several different points of view:

\subsection{The US}

The main advantage for the US would be the opportunity to share with its partners the burden and responsibility of acting as 'global policeman', which no single nation has the right to assume in any case. In these times of financial stringency, the cost is a major consideration. In recent years, the astronomical cost of the wars in Iraq and Afghanistan, plus an expenditure on armaments roughly equivalent to the rest of the world put together, has taken a heavy toll on the US budget, so that the national debt stood at around 100\% of GDP, even before the COVID-19 crisis. Action to cut costs needs to be taken urgently, and sharing more of the security burden would help enormously. A move towards shared responsibility and collective security is clearly the right thing to do in any case.

The fact that spokesmen on both sides of US politics have advocated somewhat similar ideas indicates that a scheme of this sort should have a good chance of acceptance in the US, and if the US leads the way, the other members of NATO and the OECD are very likely to follow.

\subsection{Europe}

Europeans have already had long experience with transnational cooperation through the European Union. The Chancellor of Germany, Angela Merkel, is very much in favour of multilateral cooperation, as is the President of France, Emmanuel Macron. A former Prime Minister of France, Edouard Balladur, has gone so far as to suggest a full union between the USA and Europe to deal with the full range of global foreign policy issues (Balladur, 2007).

Despite this, the Europeans have apparently been very wary of the idea of a 'global NATO', being fearful of being dragged into neo-imperialist adventures under the dominance of the United States. These fears would be answered by an explicit declaration that the new Community would never use force to intervene in an external state unless authorized to do so by the Security Council, or else if it was itself under external attack. Furthermore, under a qualified majority voting scheme the US would have the largest voice, but by no means a dominant voice, in the councils of the Community. The introduction of qualified majority voting would give the Europeans a full voice in the decisions of the Community.

Recently, debate has been revived in Europe as to whether a European army should be set up. Jean-Claude Juncker, the President of the European Commission, called for the EU to create a "common military force", including a command headquarters in Brussels. "We have to take responsibility for protecting ourselves and the European way of life”, he said (Juncker, 2016). Such pan-European forces could play an important role within the Community’s military structure.

\section{Conclusions}

In summary, the new Community would bring many benefits. It would cure some of the major problems within the present NATO system. It would produce a powerful new global security community, which acting in tandem with the 
Security Council would be a strong force for peace and freedom in the world.

Spokesmen on both sides of politics in the US have put forward similar schemes in the past, so there is a good chance that a plan of this sort would be acceptable to the USA. The Europeans would most likely be happy to follow, and so the proposal should have a good chance of being implemented.

As noted previously, this scheme is envisaged as only the first stage in a process of global integration. If the Community is open to new members, subject to suitable criteria of democracy and peaceful relations with their neighbours, then one can envisage many new members joining up, attracted by the assurance of guaranteed security, together with the prospect of new structural adjustment funds coming their way. The membership could soon include the majority of the world's nations, as more countries become democratic. Eventually, one may hope that membership in the Community would become universal.

The European Union provides a useful template for this process. The EU has devoted a large fraction of its budget to 'structural development' funds, aiming to help the less developed member states to catch up with the rest under the principle of 'solidarity'. We would hope the new Community would spend an increasing fraction of its total budget in this way, and thus follow the Biblical injunction of 'beating their swords into plowshares'.

One possibility is that the OECD could be folded into the new Community to undertake this role. In its earlier glory days following World War II, this organization played a similar role in managing the Marshall Plan for the reconstruction of Europe.

With the addition of a Court, and the adoption of qualified majority voting, the association would become a community on the European model. It would provide a convenient forum for discussion and the making of common policy on matters beyond the security sphere, including trade, finance and the environment.

Future stages, following the example of the European integration process, could involve:

- A Federal Union of Democratic Nations, as envisaged by Clarence Streit many years ago (Streit, 1939), and later advocated by the Atlantic movement (Deutsch, 1957; Yuncker, 2018);

- And eventually, a genuine, universal and democratic world federation, capable of managing effectively and overcoming the serious global challenges which confront all of us in common.

Such a global parliament or world federation would help enormously in managing the severe global problems which are facing us. It would involve a binding system of world law, ensuring the peaceful settlement of any international disputes. The great powers could then safely discard their nuclear weapons, finally removing this catastrophic risk for ever.

The global parliament would also provide a proper forum for making decisions on how to prevent further climate change and preserve the global common environment, while sharing the financial burden in a just and fair manner. It would enable us to address other global problems in a much more effective manner. In fact, it would open up a whole new and bright future for humanity, as prophesied long ago by H.G. Wells in his great work The Outline of History:

"There can be little question that the attainment of a federation of all humanity, together with a sufficient measure of social justice, to ensure health, education and a rough measure of equality of opportunity to most of the children born into the world, would mean such a release and increase of human energy as to open a new phase in human history." (Wells, 1922)

The Summit of Democracy proposed by President Biden during his first year in office (Biden, 2020) could provide an ideal starting point for this scheme. As noted in the Introduction, we would like to see:

1) The Summit should become a yearly event, to function as a council of heads of government to coordinate and plan cooperation between the community of democratic nations around the world;

2) Ideally, the Summit should set up a commission to draft a new Treaty establishing either a new global alliance or a global Community such as we have outlined here, modelled after the Treaty of Rome in Europe.

\section{Acknowledgements}

I am very grateful for extensive discussions on this topic with my colleagues on the Coalition for a World Security Council, and particularly with Didier Jacobs and John Davenport.

\section{References}

Aznar, Jose Maria (2006). NATO: An Alliance for Freedom. RUSI 151, no. 4 http://www.rusi.org/go.php?structureID $=$ articles_journal\&ref=A44DCA72D99D0C.

Balladur, Edouard. (2007). Pour une Union occidentale entre l’Europe et les Etats-Unis. Paris: Fayard. 
Baratta, J. P. (1989). The International History of the World Federalist Movement. Peace and Change 14, 372.

Biden, Joseph R., Jr. (2020). Why America Must Lead Again: Rescuing U.S. Foreign Policy After Trump. Foreign Affairs, March/April issue. See https://www.foreignaffairs.com/articles/united-states/2020-01-23/why-americamust-lead-again.

CUNPA. Campaign for a United Nations Parliamentary Assembly, http://en.unpacampaign.org/.

Coalition 2018. Coalition for a World Security Community of democratic nations, https://worldsecuritycommunity.org/.

Commission for the Human Future 2020. Surviving and Thriving in the $21^{\text {st }}$ Century. See http://humansforsurvival. org/sites/default/files/CHF_Roundtable_Report_March_2020.pdf.

Copenhagen Charter 2021. See https://www.allianceofdemocracies.org/initiatives/the-copenhagen-democracy-summit/ copenhagen-charter/.

Daalder, Ivo and James Lindsay. (2007). Democracies of the World, Unite. The American Interest 2, no. 3: 5-15. http://www.theamerican-interest.com/article.cfm?piece=220.

Deutsch, K.W., et al. (1957). Political Community and the NorthAtlantic Area. Princeton University Press, Princeton.

Freedom House. (2021). Freedom in the World. Annual report published by Freedom House. See https://freedomhouse.org/report/freedom-world/2021/democracy-under-siege.

Hamer, Christopher. (1998). A Global Parliament: Principles of World Federation. Oyster Bay Books. Available through Amazon.

Harmel. (1967). Report of the NATO Council, 'The Future Tasks of the Alliance', see https://www.nato.int/ cps/en/natohq/official_texts_26700.htm.

IEP. (2020). Analysing the Factors that Sustain Peace. Institute for Economics \& Peace. Positive Peace Report: See https://www.visionofhumanity.org/wp-content/uploads/2021/04/PPR-2020web.pdf.

Ikenberry, G. John and Slaughter, Ann-Marie, Co-Directors. (2006). Forging a World of Liberty under Law: U.S. National Security in the 21st Century. Final Paper of the Princeton Project on National Security http://www.princeton.edu/ ppns/report/FinalReport.pdf.

Jacobs, Didier. (2007). Global Democracy: The Struggle for Political and Civil Rights in the 21st Century. Vanderbilt University Press.

Jones, James. (2007). Stronger Political Structures for NATO. Freedom and Union 2, no. 1: 10-11.

Juncker, Jean-Claude. (2016). We need a European army. See http://www.bbc.com/news/world-europe-31796337.

Leinen, Jo and Bummel, Andreas. (2018). A World Parliament: Governance and Democracy in the 21st Century. Democracy without Borders, Berlin. A recent, detailed and comprehensive account of the world federalist movement, and the campaign for a UN Parliamentary Assembly.

Mackay, R. W. G. (1969). Toward a United States of Europe. Hutchinson, London.

McCain, John. (2007). McCain Remarks. Hoover Institution\| (speech, Stanford University, Stanford, CA, May 1, 2007). http://media.hoover.org/sites/default/files/documents/McCain_05-01-07.pdf.

Monnet, Jean. (1978). Memoirs, translated by R. Mayne. Collins. London.

Nathan, Otto and Nordern, Heinz. (1968). Einstein on Peace. SchockenBooks, New York, p. 336.

Naumann, Klaus, et al. (2007). Towards a Grand Strategy for an Uncertain World—Renewing Transatlantic Partnership. http://www.worldsecuritynetwork.com/documents/3eproefGrandStrat(b).pdf

Rasmussen, Anders Fogh.(2016). The Will to Lead: America's Indispensable Role in the Global Fight for Freedom. Broadside Books, New York.

Schuman 1950. The Schuman Declaration, https://europa.eu/european-union/about-eu/symbols/europe-day/schumandeclaration_en.

Streit, Clarnce K. (1939). Union Now! Harper \& Brothers, New York.

Thomas, Jason. (2018). Pacific Alliance our SafestBet. Opinion piece, The Australian, October 30.

Warsaw Summit Communique. (2016). http://www.nato.int/cps/en/natohq/official_texts_133169.htm.

Wells, H. G. (1922). The Outline of History. George Newnes, London, p. 754 
WFM-IGP. The World Federalist Movement-Institute for Global Policy. See http://www.wfm-igp.org/.

Yuncker, James. (2014). Global Marshall Plan: Theory and Evidence. Lexington.

Yuncker, James. (2018). Evolutionary World Government: Approach to Global Federation. Hamilton. 